\title{
Covid-19: Helsepersonell får hudproblemer av beskyttelsesutstyret
}

Masker, beskyttelsesbriller og visir gir trykksår på nesen og pannen. Strikken gnager bak ørene. Huden i ansiktet og på hendene blir tørr, sprekker og klør. Hva kan du gjøre for å minimere slike problemer?

\section{Arne Langøen}

Dosent

Institutt for helse- og omsorgsvitskap, Høgskulen på Vestlandet

Isabella Stokka Landmark

Sårsykepleier

Kirurgisk avdeling, Stord sjukehus, Helse Fonna

Bodo Erhardt Günther

Overlege

Kirurgisk avdeling, Stord sjukehus, Helse Fonna

\section{Covid-19}

Beskyttelsesutstyr

Hudproblemer

Trykksår

\section{Hovedbudskap}

I disse dager står helsevesenet i store deler av verden overfor en gigantisk utfordring $\mathrm{i}$ forbindelse med covid-19-pandemien. For å kunne behandle så smittsomme pasienter må helsepersonell bruke store mengder beskyttelsesutstyr. Dette utstyret gir trykk mot huden. I denne artikkelen oppsummerer vi det vi vet i dag om disse problemene, og hva som kan gjøres både for å forebygge og behandle dem. 
Da covid-19-infeksjonen eskalerte i den kinesiske provinsen

Hubei i januar og februar 2020, fikk samfunnet og

helsevesenet mange og store utfordringer.

En - tross alt - liten utfordring som mange helsearbeidere i

Wuhan opplevde, var at bruken av beskyttelsesutstyr for å beskytte seg mot viruset medførte mange hudproblemer, både i ansiktet og på hendene. Så mye som 97 prosent av helsearbeiderne i Wuhan meldte at de fikk hudproblemer på grunn av beskyttelsesutstyret (1).

\section{$\equiv$ «97 prosent av helsearbeiderne i Wuhan meldte at de fikk hudproblemer på grunn av beskyttelsesutstyret.»}

Hvordan arter disse problemene seg, hva er grunnene til at de oppstår, og hva kan vi gjøre for å minimere dem? Disse spørsmålene ønsker vi å drøfte i denne artikkelen.

Forståelig nok har vi liten kunnskap om disse spørsmålene, i og med at de først oppsto vinteren og våren 2020. Noen mindre grupper av helsearbeidere har vært vant med å bruke beskyttelsesutstyr, som for eksempel på brannskadeavdelingen, men ikke i et slikt omfang og på den måten vi ser i forbindelse med covid-19-pandemien.

\section{Pasienter med hudproblemer er velkjent}

Imidlertid er det et kjent problem med hudproblemer for pasienter som må bruke medisinsk utstyr som CPAP (kontinuerlig positivt luftveistrykk), oksygenmasker, respiratorer og annet overvåkningsutstyr.

I 2019 ble det nedsatt en internasjonal ekspertgruppe som fikk i oppdrag å oppsummere det vi vet om hudproblemer knyttet til denne typen utstyr.

Gruppen leverte sin rapport i mars 2020 (2). I rapporten kalles disse hudproblemene for device-related pressure ulcers (DRPU), altså trykkskader forårsaket av medisinsk utstyr.

I rapporten er de særlig opptatt av to pasientgrupper: voksne intensivpasienter og premature barn. Det er primært i disse gruppene DRPU-relaterte problemer oppstår. 
En gruppe portugisiske helsearbeidere har så, delvis basert på den ovennevnte rapporten (2), laget en veileder for å minimere hudproblemer hos ansatte som bruker beskyttelsesutstyr når de behandler covid-19-infiserte pasienter.

\section{Ansatte i Wuhan fikk hudproblemer}

I februar 2020 gjennomførte kinesiske forskere en unders $\varnothing$ kelse blant helsearbeidere som hadde behandlet covid-19-pasienter i Wuhan. De skulle svare på i hvilken grad de opplevde hudproblemer knyttet til bruk av beskyttelsesutstyr.

I artikkelen ble dette utstyret kalt Personal Protective Equipment (PPE), som vi i denne artikkelen har kalt «beskyttelsesutstyr». Lan og medarbeidere sendte et spørreskjema til 700 helsearbeidere, og 542 (77,4 prosent) svarte på dette (1). En noe uferdig artikkel basert på denne unders $\varnothing$ kelsen er allerede publisert.

Unders $\varnothing$ kelsen viser at nesten alle (97 prosent) fikk en eller annen form for hudproblem som følge av bruken av beskyttelsesutstyr. Det største problemet var relatert til bruken av masker, beskyttelsesbriller og visir, med påfølgende hudskader på nesen og pannen (83,1 prosent).

Andre vanlige symptomer er tørr hud, kløe, hudsprekker på hendene og i ansiktet (70,3 prosent). Det var klar sammenheng mellom tiden beskyttelsesutstyret ble brukt, og andelen som fikk problemer.

Eksempelvis fikk 81,7 prosent av dem som brukte ansiktsmasken N95 i mer enn seks timer av gangen, hudproblemer som følge av dette, mens andelen sank til 68,9 prosent når de brukte denne masken i mindre enn seks timer per dag.

Problemene som ble registrert i unders $\varnothing$ kelsen (1), illustreres i tabell 1. 


\begin{tabular}{llc}
\hline Hjelpemiddel & Hvor oppsto problemet & Andel som fikk hudskade \\
\hline N95-ansiktsmaske & Kinnet & $<6$ timer: 68,9 prosent \\
& & $>6$ timer: 81,7 prosent \\
\hline Vernebriller & Nesebroen & $<6$ timer: 75,8 prosent \\
& & $>6$ timer: 87,9 prosent \\
\hline Ansiktsvisir & Pannen & $<6$ timer: 48,1 prosent \\
\hline Hansker & $>6$ timer: 58,6 prosent \\
\hline & Hendene ble vasket mindre & $<6$ timer: 58,8 prosent \\
& enn ti ganger om dagen & $>6$ timer: 63,9 prosent \\
\hline Hendene ble vasket mer & $<6$ timer: 76,3 prosent \\
& enn ti ganger om dagen & $>6$ timer: 76,8 prosent \\
\hline
\end{tabular}

Disse tallene er kun basert på en enkelt undersøkelse, så prosentandelen vil kunne variere med hvilket utstyr som benyttes, og hvilke andre forhold som spiller inn. Denne unders $\varnothing$ kelsen tillater likevel konklusjonen at langvarig bruk av beskyttelsesutstyr kan gi betydelige hudproblemer.

\section{Hvorfor oppstår hudproblemer?}

Grovt sett kan hudskadene deles inn i to grupper:

- Den ene gruppen har skader forårsaket av trykk. Trykk gir noen skader på hudens overflate, men kan også gi skader dypere i huden (2).

- Den andre gruppen har skader på hudens overflate forårsaket av fuktighet, $\mathrm{pH}$-endringer, hyppig bruk av såpe og vann, friksjon og okklusjon $(3,4)$.

Trykkrelaterte skader forårsakes, i denne sammenhengen, av beskyttelsesbriller, visir og ansiktsmasker. Trykk forårsaker to typer problemer: Dels avklemmes blodsirkulasjonen i et avgrenset område av dermis. Sirkulasjonen i dermis ernærer epidermis, som dermed får nedsatt tilførsel av næring og oksygen.

Like viktig er det at strukturer i subkutis, muskellaget og ekstracellulær matriks kan bli skadet som følge av deformasjon av cellene (2). Jo lenger maskene benyttes, dess større er risikoen for at cellene i subkutis og muskelvevet blir deformert og tar skade.

Hvis de røde merkene etter beskyttelsesutstyret ikke er forsvunnet en halv time etter at masken ble fjernet, foreligger det en permanent trykkskade (5). 
Skadene på hudens overflate har en mer blandet årsakssammenheng. Også her har hudstatus før beskyttelsesutstyret tas i bruk betydning. Personer som lett får tørr og kløende hud, er mer utsatt for hudskader forårsaket av beskyttelsesutstyret.

Overflatiske hudskader har sammenheng med at bruk av beskyttelsesutstyret fører til følgende $(3,4,6)$ :

- $\varnothing$ kt fuktighet under masker, briller og hansker

- hyppigere håndvask

- høyere hud-pH

- større friksjon på grunn av fuktighet

- allergiske og toksiske reaksjoner

- nedbryting av hudbarrieren

- akne

- kløe og tørr hud

Mange av disse problemene er kjent for personer som jobber på operasjonsstuer, slik som kirurger og operasjonssykepleiere. Men de fleste av dem slipper å benytte denne typen beskyttelsesutstyr hele dagen, hver dag.

Denne gruppen helsepersonell har lang erfaring med å bruke beskyttelsesutstyr og dermed også bedre kompetanse på å beskytte huden.

\section{Hvordan kan skader unngås?}

Det er avgjørende å forebygge slike skader for å kunne utføre behandling og pleie av pasienter med covid-19-infeksjon. Oppstår det først hudproblemer, kan det være utfordrende å behandle dem samtidig som du skal fortsette å benytte beskyttelsesutstyr for å kunne utføre jobben.

\section{Forbered huden på belastningen}

Alt som kan redusere hudens evne til å håndtere belastningen av beskyttelsesutstyret, bør unngås i denne perioden. Unngå sterke vaskemidler, begrens bruken av sminke og unngå mye sollys som kan svekke huden. Hvis man er plaget av tørr hud, kan hudpleiemidler med høyt innhold av fett hjelpe (7). 


\section{Beskytt huden mot fuktighet og endringer av hudens $\mathrm{pH}$}

Vi har to alternative løsninger som er aktuelle: Du kan enten beskytte huden ved hjelp av et fettrikt hudpleieprodukt eller benytte hudfilm, også kalt barrierefilm (akrylatholdig hudbeskyttelse) (7). Du bør velge enten fettholdige hudpleieprodukter eller barrierefilm.

Hvis du skal benytte trykkfordelende bandasjer, som hydrokolloider, skumbandasje eller liknende, skal det ikke benyttes fettholdige hudpleieprodukter, da de vil hindre at bandasjen fester seg på huden. Derimot vil barrierefilm medføre at bandasjen fester seg bedre, og huden blir mindre skadet når bandasjen fjernes.

Vær obs på at det tar 72 timer før hudfilmen er borte fra huden. Om du for eksempel skal behandle en dermatitt med kortisonkrem i denne perioden, vil den ikke være effektiv før barrierefilmen er borte.

\section{Unngå for lange sammenhengende perioder med beskyttelsesutstyr}

Som den kinesiske studien viste, har tiden beskyttelsesutstyret benyttes, stor betydning for hvor mye skade huden får (1). Det er derfor viktig ikke å ha for lange sammenhengende perioder hvor du har på seg beskyttelsesutstyr.

Forutsatt at tilgangen på slikt utstyr er god nok, bør du ikke ha det på mer enn fire til seks timer om gangen, hvis det er praktisk gjennomførbart.

\section{Skift jevnlig beskyttelsesutstyr som gir trykk}

Ulike varianter av visir, beskyttelsesbriller og ansiktsmasker gir ulikt trykk. Opplever du trykk over nesen med briller, kan det være nyttig å bytte til visir, selv om det også gir trykk, men på et annet område i ansiktet. Ulike ansiktsmasker gir ulikt trykk. Bytter du jevnlig, avlastes trykket.

\section{$\equiv$ ¿Ulike ansiktsmasker gir ulikt trykk. Bytter du jevnlig, avlastes trykket.»}

\section{Benytt trykkfordelende hjelpemidler i ansiktet}

Kunnskapen om hvordan man kan beskytte huden i ansiktet mot trykk fra hjelpemidler, kommer først og fremst fra studier gjort av intensivpasienter som for eksempel ligger lenge på respirator med maske og tuber. 
De fleste unders $\varnothing$ kelsene konkluderer med at man kan bruke barrierefilm, plastfilm, hydrokolloider, skumbandasjer eller silikonpads til å beskytte huden. Vi fant ingen studier av høy kvalitet som kan gi oss en klar indikator på hvilke produkter som skiller seg mest positivt ut, men vi kan forvente at tykkere materialer vil gi bedre polstring.

Weng (8) sammenliknet effekten av plastfilm (Tegaderm) med en hydrokolloid (Tegasorb), og begge produktene halverte forekomsten av trykkskader i ansiktet hos intensivpasienter som brukte maske. I denne studien kom hydrokolloidene litt bedre ut enn plastfilmen.

Vi kan forvente et slikt resultat siden hydrokolloider er litt tykkere, men forskjellene i tallene var ikke så store.

Konklusjonen her ble at det ikke skal så mye til for å beskytte huden. Til og med en relativt tynn plastfilm ga en signifikant reduksjon av hudskader.

Vi fant ellers en del litteratur som omhandler beskyttelse av huden på områder rundt trakeotomier, rundt diverse dren og bak ører. En grei oppsummering er gjort av Fletcher i Wounds UK (9).

Hvis vi nå fokuserer på masker som beskytter mot aerosol, er utfordringen at valg av polstringsmaterialet ikke må gå på bekostning av tettheten av masken vi bruker. Her finnes det overhodet ingen litteratur ennå, og inntil videre er man nødt til å bruke sunn fornuft.

Vi forventer at en flerlags skumbandasje gir best polstring mot trykk, men bekymringen her er altså at masken muligens ikke vil sitte tett nok på.

\section{$\equiv$ ¿Det er spesielt avgjørende at masken sikrer at virus fra aerosolen ikke passerer forbi masken.»}

For helsearbeidere som jobber med covid-19-pasienter på en intensivavdeling, der det er $\varnothing \mathrm{kt}$ fare for smitte via aerosoler $\mathrm{i}$ forbindelse med arbeidet nær intuberingsområdet, er det spesielt avgjørende at masken sikrer at virus fra aerosolen ikke passerer forbi masken.

Vi kan derfor ikke gå ut med en anbefaling om å bruke flerlags skumbandasjer som polstring rundt ansiktsmaskene inntil dette er unders $\varnothing \mathrm{kt}$ nærmere. 


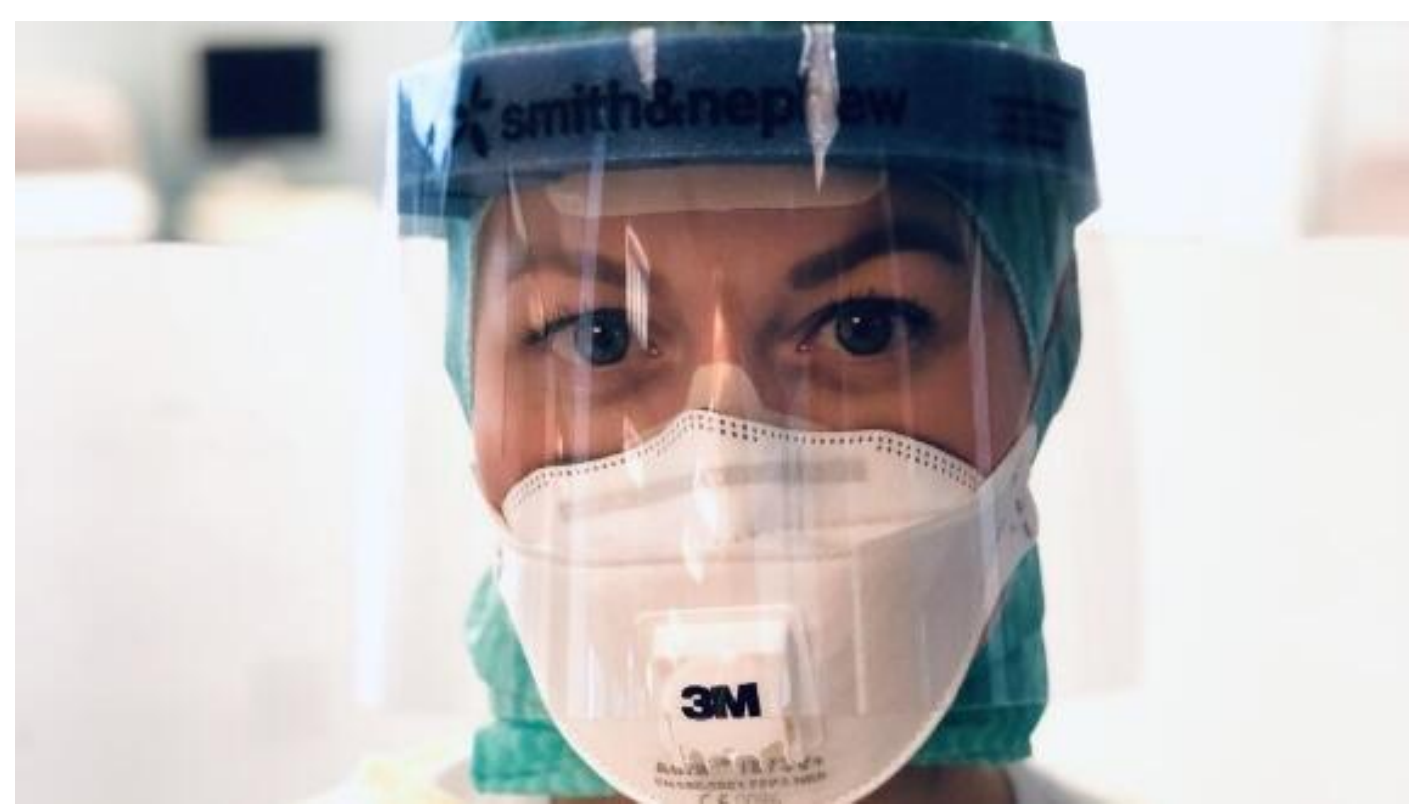

GODT POLSTRET: Under arbeid med covid-19-pasienter er helsearbeidere spesielt utsatt for trykk fra masken over nese- og kinnpartiene og fra strikken bak øret. I panneregionen er det fare for trykk fra visirbåndet. Her er det brukt et visir fra Smith \& Nephew. Denne modellen er veldig godt polstret og vil sannsynligvis gi færre utfordringer. Det er stor forskjell på kvaliteten på og polstringen av disse hjelpemidlene. Foto: Stord sjukehus, Helse Fonna

Som nevnt ovenfor viste Weng (8) at også tynne materialer kan gi en overraskende god polstring. For å sikre at masken gir en maksimal antiviral beskyttelse, bør du velge et relativt tynt materiale som polstring slik at masken holder ordentlig tett.

Her finnes det heller ingen studier vi kan støtte oss på, og våre anbefalinger baserer seg på våre egne kliniske erfaringer og vår personlige kunnskap om produktenes egenskaper.

Vi mener at et lag med barrierefilm på huden - bruk pensler eller wipes og ikke spray for å unngå å få produktet i фyet - vil være fornuftig for å få polstringsproduktene til å sitte bedre og minimere irritasjon på huden generelt.

Slike produkter kan påføres én gang daglig. Det er viktig å unngå bruk av fettholdig krem eller sminkeprodukter på ansiktet før man har påført slike barriereprodukter.

Som polstringsmateriale rundt masker som beskytter mot aerosol, anbefaler vi teip med silikonbelegg, ekstra tynne skumbandasjer med silikonbelegg (finnes også på rull), hydropolymerplater eller hydrokolloider.

Alle materialene i disse produktgruppene lar seg lett klippe til, og de sitter godt. De er hudvennlige og så tynne at de ikke bør gå på bekostning av tettheten av masken. 


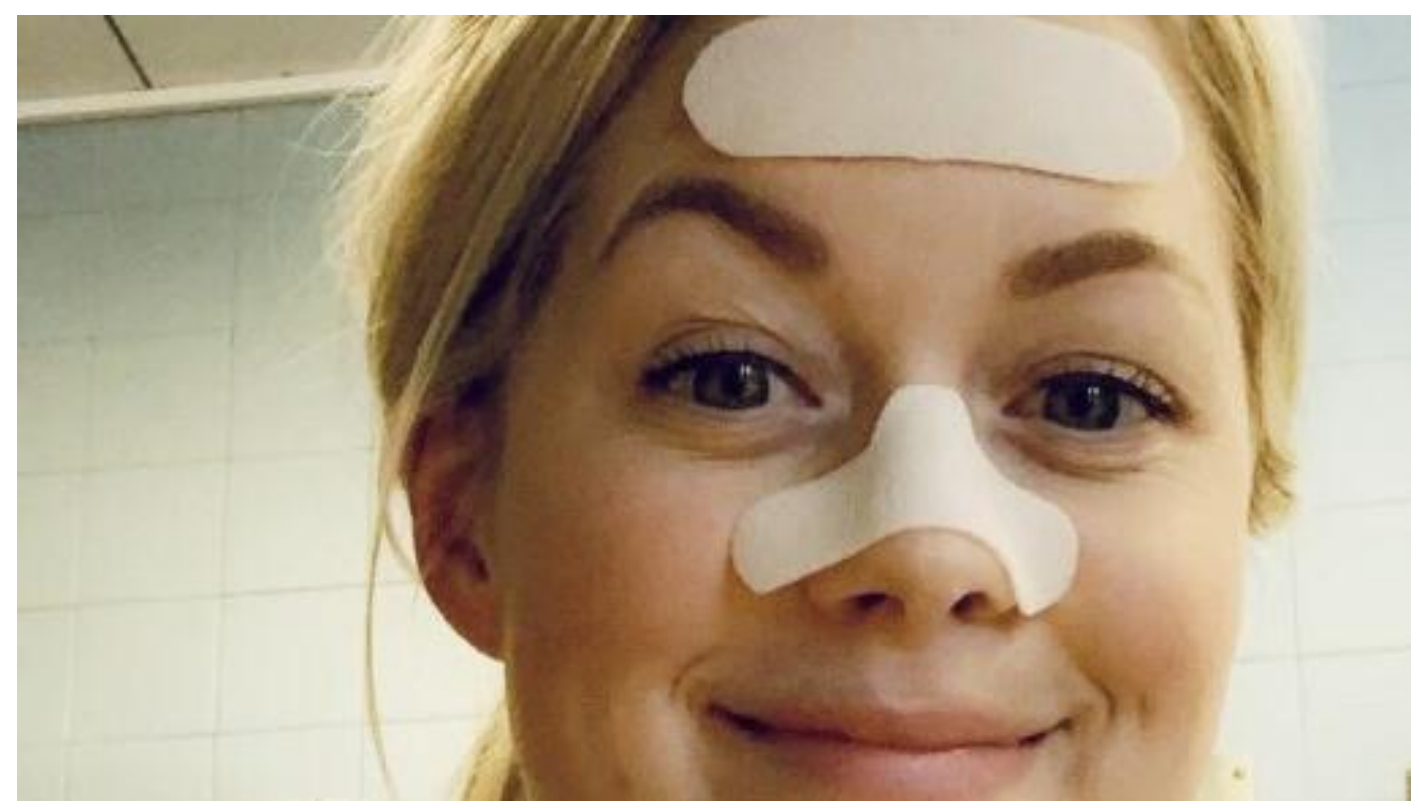

BESKYTTER MOT TRYKKSÅR: Studier viser at selv relativt tynne polstringsprodukter kan forebygge trykkskader som oppstår ved bruk av hjelpemidler i ansiktet. Her er det et eksempel på hvordan man kan klippe til en ekstra tynn silikonbelagt skumbandasje for å tilpasse den over nesen og i pannen. I tillegg kan man polstre over kinnpartiene. Slike tynne polstringsprodukter bør sikre at masken fortsatt ligger tett mot ansiktet uten å gå på bekostning av beskyttelsen mot smitteoverføring. Foto: Stord sjukehus, Helse Fonna

For polstring i panneområder, over og bak ørene kan du bruke tykkere polstringer, da disse områdene ikke berører kanten av masken. Her kan du bruke produkter som nevnt ovenfor.

I tillegg kan også flerlags skumbandasjer med silikonbelegg benyttes. Det finnes dessuten selvklebende silikonplater som egner seg godt i disse hudområdene. Også til disse områdene anbefaler vi å bruke barriereprodukter på huden først.

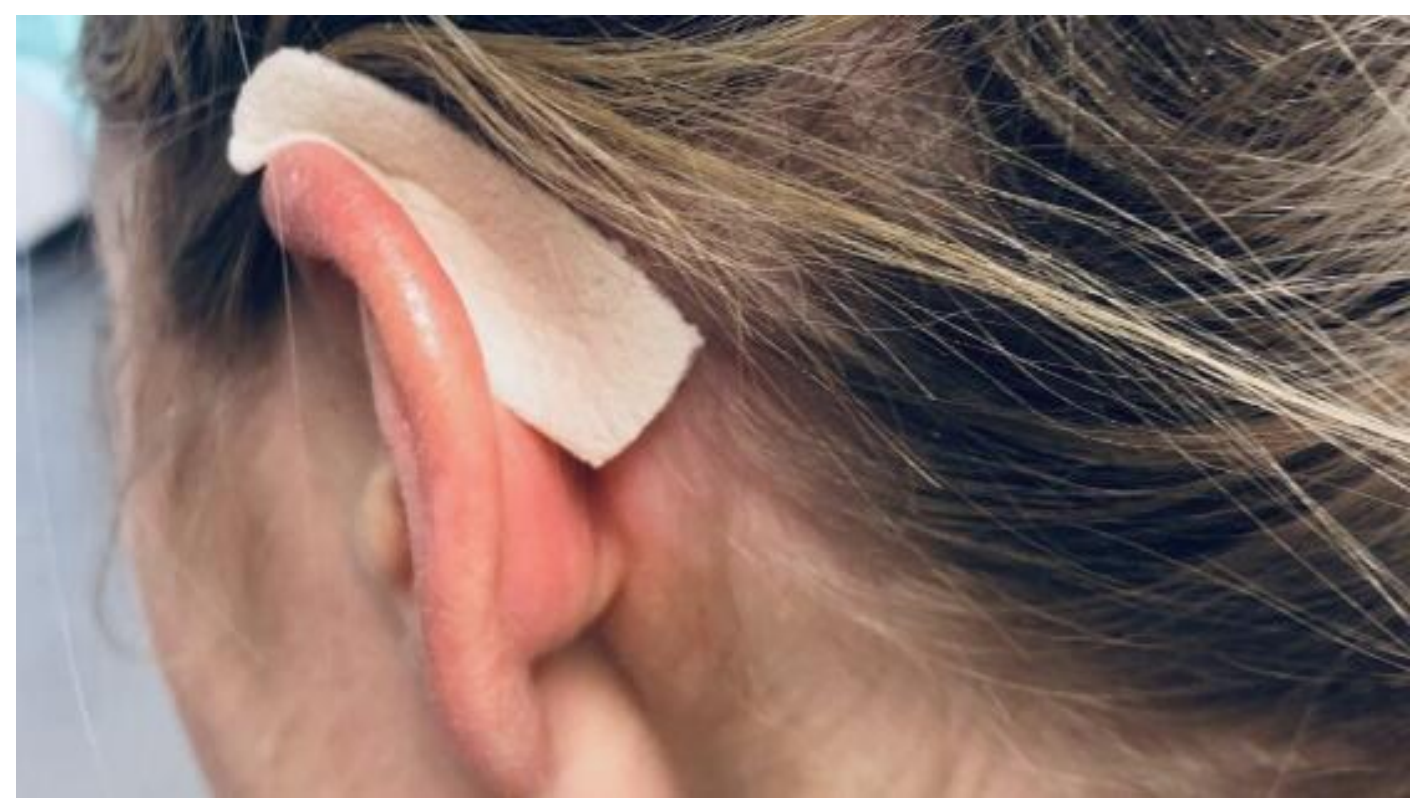

NÅR MASKESTRIKKEN TRYKKER: Med en selvklebende bit av silikonbelagt skumbandasje eller skumteip kan man effektivt polstre baksiden av øret og beskytte mot trykk fra maskestrikken. Foto: Stord sjukehus, Helse Fonna 
Vi har laget en oversikt over produktgruppene og

bruksområdene i tabell 2.

Tabell 2. Oversikt over produkter som egner seg til å beskytte ansiktet ved bruk av maske eller visir

\begin{tabular}{|c|c|}
\hline Beskyttelse rundt P3-, P2- og PPT-maske & Eksempler \\
\hline Hudbarriereprodukter & Secura, Cavilon, Silesse \\
\hline Teip med silikonbelegg & Mepitac \\
\hline Ekstra tynne skumbandasjer & $\begin{array}{l}\text { Mepilex Lite, 3M Microfoam (rull), } \\
\text { Allevyn Thin, Askina, Calgitrol Thin }\end{array}$ \\
\hline Hydropolymerbandasjer & Cutimed Hydrocontrol \\
\hline Hydrokolloidbandasjer & $\begin{array}{l}\text { Comfeel, Duoderm, Hydrocoll, Suprasorb, } \\
\text { Tegaderm Hydrocolloid }\end{array}$ \\
\hline Beskyttelse i pannen og bak ørene & Eksempler \\
\hline \multicolumn{2}{|c|}{$\begin{array}{l}\text { Her anbefaler vi også bruk av barriereprodukter på huden først, } \\
\text { før man fester selve polstringsproduktet. Alle produktene nevnt } \\
\text { ovenfor kan brukes her, men siden disse områdene ikke berører } \\
\text { kanten av masken, kan man også velge tykkere produkter. }\end{array}$} \\
\hline Flerlags skumbandasjer med silikonbelegg & $\begin{array}{l}\text { AllevynLife, Aquacel Foam, Foamlite } \\
\text { Convatec, Askina Foam, Biatain Foam, } \\
\text { Mepilex Foam, Suprasorb P, Tielle Foam, } \\
\text { Kliniderm Foam }\end{array}$ \\
\hline Silikonplater eller -rull & A-derma Skin \\
\hline \multicolumn{2}{|c|}{$\begin{array}{l}\text { Listen over produktene er ikke komplett og baserer seg i hovedsak på produkter som er tilgjengelige i Norge. Våre anbefalinger } \\
\text { støtter seg på våre egne kliniske erfaringer og personlig kunnskap om produktene, da det ikke finnes gode studier på dette } \\
\text { omrádet om hudbeskyttelse av helsepersonell. Vi tar dessuten forbehold om eventuelle feil i beskrivelsen av produktene. }\end{array}$} \\
\hline
\end{tabular}

\section{Ta vare på hendene}

Som unders $\varnothing$ kelsen fra Kina viste, er hyppig håndvask med såpe og vann eller bruk av håndsprit tøft for huden på hendene (1). Samtidig er det vesentlig å beskytte huden slik at du unngår sprekker og sår. I tillegg til å være et hygienisk problem er slike sprekker og sår en stor personlig belastning $i$ form av smerter og svie.

Langøen (10) anbefaler følgende for å ivareta hendene:

- Vask hendene så sjelden som mulig, men så ofte som nødvendig.

- Vær nøye med valg av håndsåpe. Alkaliske såper (såpestykker) skader huden mer enn lav-pH-vaskemidler.

- Prøv alternative håndvaskemidler som vaskekrem, håndsprit eller superoksiderte væsker. Superoksiderte væsker er relativt nye i denne sammenhengen, men de er et fullverdig og mer hudvennlig alternativ til håndsprit. Når man først har fått eksem på hendene, er håndsprit skikkelig ille. Et aktuelt produkt er Verifortehånddesinfeksjon. Dette produktet finnes også som gel.

- Bruk beskyttelseshansker.

- Prøv å bruke en beskyttelseskrem eller en barrierekrem. De skal benyttes forebyggende. Husk samtidig at noen av dem vil hemme virkningen av andre produkter som smøres på huden. Det har sammenheng med at de legger seg som et beskyttende lag over huden. 
Smør hendene med en lett, vannholdig krem eller en

- lotion mange ganger i løpet av arbeidsdagen. Hvis det er mulig mellom hanskeskift, kan huden tilføres fuktighet.

- Hendene smøres med fettholdige produkter på slutten av dagen, for eksempel om kvelden for å bedre hudens beskyttende evne.

- Kortisonkrem eller -salve kan brukes for å dempe inflammasjonen i de verste periodene. Disse bør smøres på om kveldene slik at de får lang nok tid til å virke. Man kan prøve gruppe 1-kortisonprodukter ved mild eksem. Ved mer uttalt dermatitt må man vurdere å bruke gruppe 3-kortisonprodukter i kortere perioder.

\section{Referanser}

1. Lan J, Song Z, Miao X, Li H, Li Y, Dong L, et al. Skin damage among healthcare workers managing coronavirus disease-2019. J Am Acad Dermatol. 2020;So19o9622(20)30392-3. DOI: 10.1016/j.jaad.2020.03.014

2. Gefen A, Alves P, Ciprandi G, Coyer F, Milne CT, Ousey K, et al. Device-related pressure ulcers: SECURE prevention. J Wound Care. 2020;29(Sup2a):S1-S52.

3. Alves PM, Vaz A, Ferreira A, Malcato E, Mota F, Afonso G, et al. PRPPE guideline COVID 19. Prevention of skin lesions caused by Personal Protective Equipment (face masks, respirators, visors and protection glasses). Journal of Tissue Healing and Regeneration. $202 \mathrm{O}$.

4. Darlenski R, Tsankov N. Covid-19 pandemic and the skin - What should dermatologists know? Clinics in Dermatology. 2020; 24. mars. DOI: 10.1016/j.clindermatol.2020.03.012

5. Langøen A, Gürgen M. Forebygging og behandling av sår. Etiologisk inndeling. I: Langøen A, red. Sårbehandling og hudpleie. 5 utg. Oslo: Gyldendal Akademisk; 2018.

6. Elston DM. Occupational skin disease among healthcare workers during the coronavirus (COVID-19) epidemic. Letter from the editor. J Am Acad Dermatol. 2020; So190-9622(20)30390-X. DOI: 10.1016/j.jaad.2020.03.012

7. Tønnesen H. Preparater til behandling av hud. I: Langøen A, red. Sårbehandling og hudpleie. Oslo: Gyldendal Akademisk; 2018. s. 37-88. 
8. Weng MH. The effect of protective treatment in reducing pressure ulcers for non-invasive ventilation patients. Intensive Crit Care Nurs. 2008;24(5):295-9.

9. Fletcher J. Device related pressure ulcers made easy. Wounds UK. 2012;8:1-4.

10. Langøen A. Stell av frisk hud som utsettes for store påkjenninger. I: Langøen A, red. Sårbehandling og hudpleie. Oslo: Gyldendal Akademisk; 2018. s. 151-78. 